Jurnal Agro 8(2), 2021

\title{
SAPONINS ACCUMULATION AND ANTIMICROBIAL ACTIVITIES ON SHALLOT (Allium cepa L.) FROM MARGINAL LAND
}

\section{AKUMULASI DAN AKTIVITAS ANTIMIKROBA SAPONIN PADA TANAMAN BAWANG MERAH (Allium cepa L.) DARI LAHAN MARGINAL}

\author{
Nur Aeni Ariyanti*, Sonia Latifa \\ Department of Biology Education, Faculty of Mathematics and Natural Sciences \\ Universitas Negeri Yogyakarta, Karangmalang, Yogyakarta - 55281 \\ *Correspondence: nuraeni@uny.ac.id
}

Accepted: 05 May 2021 /Agreed: 25 November 2021

\begin{abstract}
Saponins are one of the secondary metabolites found in Shallot (Allium cepa L.), particularly in the roots. Microclimate differences in the cultivation area are thought to have a significant impact on the production of secondary metabolites, such as saponins. This research aimed to observe the saponins content in the root of shallot plants cultivated in marginal agricultural land and their antimicrobial activity against bacteria (Ralstonia solanacearum) and fungus (Fusarium oxysporum). This research was observational research with a random sampling method. The samples were collected from the shallot plantation with two different cultivation conditions. Two varieties of 'Bima' and 'Tiron' cultivated by farmers in sandy coastal land Samas, Bantul were used. The plants were harvested at $1,1.5$, and 2 months after planting, respectively. The crude saponins extract was used to test antimicrobial activity. Shallot plants cultivated in marginal coastal sandy land produced higher saponins accumulated in their roots. The saponins production increased along with the maturity of shallot plants, both cultivated in marginal coastal sandy land and regular paddy field. The saponins extracted from the roots of shallots cultivated in both marginal and regular land showed higher antimicrobial activity than antifungal activity.
\end{abstract}

Keywords: Antimicrobial activity, Marginal land, Saponins, Shallot

\section{ABSTRAK}

Saponin merupakan salah satu metabolit sekunder yang terdapat pada bawang merah (Allium cepa L.), terutama pada bagian akar. Perbedaan iklim mikro pada lahan budidaya diduga akan berpengaruh terhadap produksi metabolit sekunder termasuk saponin. Tujuan penelitian ini adalah untuk mengetahui kandungan saponin pada bagian akar tanaman bawang merah yang dibudidayakan di lahan pertanian marginal serta aktivitas antimikrobanya terhadap bakteri (Ralstonia solanacearum) dan jamur (Fusarium oxysporum). Penelitian ini merupakan penelitian observasi dengan metode pengambilan sampel secara acak. Sampel berasal dari perkebunan bawang merah dengan dua lahan budidaya yang berbeda. Digunakan dua varietas yaitu 'Bima' dan 'Tiron' yang dibudidayakan oleh petani di daerah pantai Samas, kabupaten Bantul. Bahan

Cite this as: Ariyanti, N, A., \& Latifa, S. (2021). Saponins accumulation and antimicrobial activities on shallot (Allium cepa L.) from marginal land. Jurnal Agro, 8(2), 188-198. https://doi.org/10.15575/12524 
tanaman dipanen pada tiga waktu berbeda, yaitu 1 bulan, 1,5 bulan dan 2 bulan berturut-turut setelah tanam. Ekstrak kasar saponin digunakan untuk menguji aktivitas antimikrobanya. Tanaman bawang merah yang dibudidayakan di lahan marginal pasir pantai menghasilkan saponin yang lebih tinggi yang terakumulasi pada akarnya. Produksi saponin semakin meningkat seiring dengan umur tanaman bawang merah, baik yang dibudidayakan di lahan marginal pasir pantai maupun di lahan sawah biasa. Saponin yang diekstraksi dari akar bawang merah yang dibudidayakan di lahan marginal dan lahan biasa menunjukkan aktivitas antimikroba yang lebih tinggi daripada aktivitas antijamurnya.

Kata kunci: Aktivitas antimikroba, Lahan marginal, Saponin, Bawang merah

\section{INTRODUCTION}

During the period of growth and development, the plant produces a wide range of bioactive metabolites, the majority of which most have an important role in the plant's ability to survive in extreme conditions (Dixon, 2001). Although bioactive metabolites are produced in small amounts, they provide a considerable benefit to plants and humans who consume them. Saponins are one of the main members of glycosides, that have antifungal action in a variety of plant species (Lanzotti, 2012). There are two types of saponins, called triterpene saponins and steroid saponins. Triterpene saponins are the general form of saponins found in dicotyledonous plants. In contrast, the steroid saponins are very rare in dicotyledonous plants and can only be found in certain monocotyledonous plants (Bruneton, 1995). Shallot a family of Allium spp. is a monocotyledonous plant that produced steroid saponins.

In the Allium spp., saponins serve as one of the compounds that can suppress the occurrence of fungal infection, especially for diseases that commonly attack the shallots, onion, and leeks, namely Fusarium wilt caused by Fusarium oxysporum $f$. $s p$ (Mostafa et al., 2013; Ariyanti et al., 2015). In some cases, the production of saponins increases as the response of infection to survive. However, the response also varies depending on the infectious species. Saponins on plant leeks respond faster to infection caused by $F$. oxysporum isolate no. AF2 when compared to other isolates (Ariyanti et al., 2015). Previous research (Mostafa et al., 2013) proves that saponins did not respond to a bacterial infection.

Shallot (Allium cepa L.) is an everyday used herb, especially by Indonesians and the world in general. In Indonesia, central shallot productions are widely spread within and outside Java, covering approximately 99.000 ha. Domestic production that reaches more than 1 million $\mathrm{t}_{\text {year }}{ }^{-1}$ can only be adequate for $20 \%$ of total consumption by the Indonesian community. Shallot contains many specific metabolite compounds that can increase food flavors and aromas. Therefore, it is used in almost all cuisines. Shallot is also known for having high antioxidant content, often used as a natural remedy for cough, cold, and stomach bloating.

In the special region of Yogyakarta (DIY), central shallot productions are spread in several regencies such as Bantul and Kulon Progo. In these regencies, there are some shallot cultivation areas located in coastal sandy land near the beach. In this marginal agricultural land, many of the specific environmental factors such as soil fertility, soil temperature, air salinity, wind velocity, and solar radiation are different from regular paddy cultivation fields. Thus, it has a 
significant impact on the production of shallot's secondary metabolites.

Shallot cultivation on this marginal agricultural land has a risk to be highly affected by abiotic/environmental stresses. This area tends to have high air and soil temperature, strong wind blowing, and lack of soil water that causes negative impacts on plants' physiology. The abiotic stress can decrease the rate of photosynthesis in tomatoes and wheat (Camejo et al., 2005; Almeselmani et al., 2006). High temperatures directly affect the production of plant secondary metabolites such as flavonoids and phenylpropanoid (Wahid et al., 2007). Ultraviolet radiation can increase the accumulation of polyphenols on the leaves, and the same tendency has been found on the onion root (Wang and Feri, 2011).

Szakiel et al. (2011) claimed that saponin content is mainly affected by intrinsic and extrinsic factors. The intrinsic factors related to the growth and development stage are responsible as both of them are responsible for the maturity and physiological status of the plant. Many biotic and abiotic conditions become the extrinsic factors for saponin accumulation, including the status of completion with other plants, interaction with microbes and herbivores, water and light intensity, temperature, and also soil fertility. Furthermore, the same species could produce different saponin content while cultivated in different areas and cultivation systems.

This research aims to observe the saponin content of shallot roots plants cultivated in marginal agricultural land and its antimicrobial activity against bacteria and fungus.

\section{MATERIALS AND METHODS}

\section{Plant Materials}

Shallot plant roots were collected from marginal (M) agricultural land owned by farmers in Samas sandy coastal land, Bantul. The samples were selected based on random sampling among several varieties of shallot. Some cultivars that are commonly used by farmers are 'Crok', 'Tiron', Biru', 'Bima' and 'Thailand'. There were two cultivars selected, 'Bima' (B) and 'Tiron' (T). Both cultivars are the main cultivar used by shallot farmers in the area and they can be found in both marginal and regular areas as well at the same time. The control plant was obtained from the regular (R) paddy agricultural land in Bantul namely the 'Bima' cultivar.

The farmers started the cultivation on April 3, 2018. The first harvest was conducted on May 3, 2018-one month after planting (the first harvest), then at the age of 1.5 months (the second harvest), and the end of the planting (the third harvest). For each harvesting time, we collected 12 plants, 4-unit plants for each replication (3 replication). After harvesting, the samples were then transported to the Microbiology Laboratory, Faculty of Mathematics and Natural Sciences, to clean and dry.

\section{Climatic and Soil Condition}

The monthly average climatic condition data were collected from the Meteorology Climatology and Geophysics Agency website (https://dataonline.bmkg.go.id) including maximum temperature $\left({ }^{\circ} \mathrm{C}\right), \mathrm{RH}(\%)$, rainfall $(\mathrm{mm})$ and wind speed $\left(\mathrm{m} \mathrm{s}^{-1}\right)$ from April to August 2018 (Table 1).

According to the website of Bantul regency, the soil condition on regular ( $R$ ) land is regosol type, while soil type on marginal (M) land area is sandy soil. 
Budiyanto et al. (2020) publish some data related to the soil condition, texture, and drainage on marginal land. The data proved that sandy texture land is dominated by a sand fraction, low organic matter, and have low water content.

Table 1 . The average monthly climatic condition

\begin{tabular}{lcccc}
\hline Month & $\begin{array}{c}\mathrm{T} \\
\max \\
\left({ }^{\circ} \mathrm{C}\right)\end{array}$ & $\begin{array}{c}\mathrm{RH} \\
(\%)\end{array}$ & $\begin{array}{c}\text { Rainfall } \\
(\mathrm{mm})\end{array}$ & $\begin{array}{c}\text { Wind } \\
\text { speed } \\
\left(\mathrm{m} \mathrm{s}^{-1}\right)\end{array}$ \\
\hline April & 32.1 & 82.1 & 9.87 & 1.26 \\
May & 32.3 & 82.8 & 0.05 & 0.58 \\
June & 31.4 & 83.2 & 0.73 & 0.47 \\
July & 30.5 & 81.3 & 0.00 & 0.77 \\
August & 30.2 & 81.5 & 0.05 & 0.97 \\
\hline
\end{tabular}

\section{Saponins Extraction}

The saponin was extracted from the root of shallot plants. The clean root was dried using the oven at a temperature of $40{ }^{\circ} \mathrm{C}$ until constant weight. The samples $(0,2-0,4$ gr dry weight) were ground thoroughly with a blender and extracted three times with 100 $\mathrm{mL}$ of $\mathrm{n}$-hexane and incubated for 24 hours. After the washing process using hexane was done, advanced extraction was performed using $80 \%$ methanol. Methanol extraction was performed two times for each incubation ( 24 hours). The filtrate obtained from methanol extraction was dried using a vacuum dryer and dissolved in $100 \mathrm{~mL}$ of water and $n$-butanol (1:1 volume). The $n$ butanol fraction was separated by using a separation funnel and dried using a vacuum dryer to obtain the crude saponins.

\section{Saponins Analysis}

The crude saponin obtained from the extraction were analyzed quantitatively and qualitatively. Quantitatively, saponins content was analyzed using a spectrophotometer (Hitachi HighTechnologies Corporation, Tokyo, Japan) by Ebrahimzadeh \& Niknam (1998). Vanillin was used as the default to make the calibration curve. The thin-layer chromatography (TLC) method was obtained to analyze the saponins content qualitatively. The chloroform phase of crude saponins was dried with Nitrogen and spotted to the silica plate and developed using chloroform: $\mathrm{MeOH}$ (95:5). The TLC plates were sprayed with anisaldehyde sulfuric acid and heated at $110^{\circ} \mathrm{C}$.

\section{Saponins Antimicrobial Activity Test}

The antimicrobial activity was evaluated by using the disc diffusion method. Ralstonia solanacearum and Fusarium oxysporum were obtained from Microbiology laboratory collection. A $0.1 \mathrm{~mL}$ bacterial and fungal suspension was spread on nutrient agar (NA) (for $R$. solanacearum) and potato dextrose agar (PDA) (for $F$. oxysporum) media. The inoculated plates were treated with a $5 \mathrm{~mm}$ paper disc plug containing $25 \%, 50 \%$, and $100 \%$ of crude saponins suspensions. Chloramphenicol and Nistatin were used as positive control on antibacterial and antifungal activity tests, respectively. The plates were incubated for 48 and 72 hours at room temperature. The antimicrobial activities were measured by measuring the diameter of the clear zone developed around the paper disc.

\section{RESULTS AND DISCUSSION}

\section{Saponins Accumulation in Shallot Roots}

This study was observational research by using shallot plants as the main object cultivated in the coastal sandy land. Coastal sandy land is included in marginal land types with a low productivity rate (Rajiman et al., 
2008). The low productivity rate is closely related to the soil structure that has lower water holding capacity (Kertonegoro, 2001). In addition, oxidation of organic matter occurs faster in the coastal than regular soil caused by a large number of airs in the soil pores (Syukur, 2005). However, this can be overcome with several modifications to the cultivation techniques, which are now commonly used by farmers in the coastal sandy land area. The modifications can be by adding more organic fertilizers and using the drip irrigation method to preserve the soil water.

The TLC method could be used to validate the saponin extracted from the root of the shallot (Figure 1). According to the qualification analysis, we could see that both cultivars cultivated in marginal agricultural land (BM and TM) show intense bands compared with the control, "Bima" cultivated in ordinary agricultural land (BR). The shallot plant cultivated in the coastal sandy land was the same shallot varieties commonly planted in the regular paddy field.
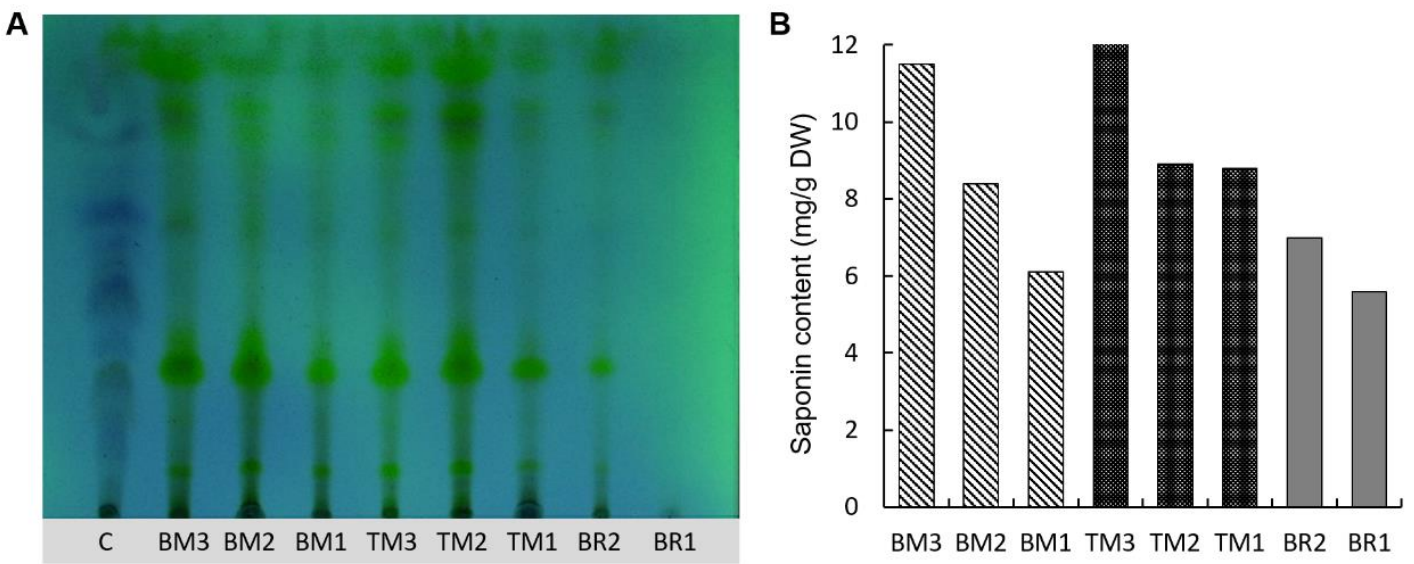

Plant materials

Figure 1. (A) Qualitative and (B) quantitative $\left(\mathrm{mg} \mathrm{g}^{-1} \mathrm{DW}\right)$ analysis of saponins in the shallot roots. 'Bima' cultivated in marginal land (BM), 'Tiron' cultivated in marginal land (TM), 'Bima' cultivated in regular land (BR) in three different harvesting times (1 month, 1.5 months, and 2 months after planting)

Both have similarities in red bulbs with adequate bulb size and produce no significantly different concentration of phytochemicals compounds, including alkenyl cysteine sulfoxide, flavonoids, and also fructan (Ariyanti et al., 2017). It indicates that both tend to have a similar flavor due to the same proportions of chemical compounds. However, there has been no research report regarding the saponin content of shallot plants cultivated in Indonesia, especially "Bima" and "Tiron".

According to the three-sampling period (1 month, 1.5 months, and 2 months after planting), the saponin concentration in the shallot plants increased along with the development of plant organs (Figure 1.B). The majority of shallot secondary metabolites are closely related to the quality of organoleptic such as pungency and the unique flavor of shallot food flavoring 
ingredients. In its production, environmental factors, both biotic and abiotic, have a very significant influence (Akula \& Ravishnkar, 2011). The greater the number of cells with the larger size, the more the cell's ability to perform primary and secondary metabolism increases. The increase of secondary metabolism allows an increase in the accumulation of secondary metabolites production such as saponin (Verpoorte \& Memelink, 2002). Moreover, environmental factors have a significant impact on saponin production.

Different cultivation will have a different impact on the production of saponins. This study observed that shallot plant roots grown in the coastal sandy land tended to have higher saponins accumulation than those grown in regular agricultural land (Figure 1). The stress conditions of the cultivation fields or abiotic stresses impacted the secondary metabolites production including saponins. The abiotic stress that occurred was triggered by the soil type (sandy), low water holding capacity, low organic matter (C-organic), higher salinity, and possibly high soil temperature (Nurhayati, 2019). These conditions lead to a lack of water availability, high light intensity, low soil fertility, and heat stress.

It has been shown that shallot roots cultivated in regular agricultural land tended to have a lower accumulation of saponin than the coastal sandy land. The results are in line with the previous research (Yang et al., 2018) that discovered saponins could be used as priming metabolites during quinoa (Chenopodium quinoa Wild.) seed germination in high salinity stress conditions. The mechanism was related to decreasing abscisic acid concentration, better osmotic and water potential, increasing photosynthesis rate, and stomatal conductance. This mechanism is related to the capability of saponins to stimulate the production of antioxidants to suppress reactive oxygen species (ROS) activity (Ismail et al., 2016).

As mentioned by Rajiman et al. (2008) and Nurhayati (2019) a high salinity level in marginal land could be one of the main problems for cultivating crops. Moreover, the wind that blows from the ocean brings salt particles that can be harmed the leaf (Laxminayana \& Subbaiah, 2015). This abiotic stress condition stimulates ROS production in the plant cell. To maintain cells metabolism, the antioxidant is needed.

Schwarzbach et al. (2006) reported that soil temperature could affect the saponin production of Asparagus officinalis. In this Asparagacea, the steroidal furostanol and spirostanol saponin were found to increase while lower soil temperature was observed. The soil temperature is also related to water availability. Drought conditions could appear in marginal land as the result of sandy soil texture. This soil could not hold water for a long period. In a high light intensity with low water holding capacity, drought stress is inevitable. The drought conditions decreased quinoa saponin content from $0.38 \%$ until $0,46 \%$ (Solı'z-Guerrero et al., 2002).

Due to the lack of organic matter in marginal land, farmers put a lot of organic fertilizer before transplanting. This not only increases the organic matter but also increases the soil fertility at the same time. The application of organic fertilizer on berry plantations could increase the saponin accumulation up to $100 \%$ especially when a good irrigation system is applied at the same time (Ndamda et al., 2006). In this study, higher saponin accumulation in the root of shallot cultivated in marginal land was 
found. This could happen because not only enough organic fertilizers were applied on the sandy soil, but also farmers put a lot of effort to maintain water ability. Together with the local government support, they prepare some ponds to collect the groundwater and surface water (Widjayanti, 2011).

To know the antimicrobial activity differences between saponins from the root of shallot cultivated in the marginal and regular area, the disc diffusion test was conducted. The saponins were tested in vitro against $R$. solanacearum and $F$. oxysporum. While for the control treatment, chloramphenicol and nystatin were used. The results show that saponins from both cultivars tend to have higher antimicrobial activity than antifungal activity (Table 2 ).

Table 2. Antimicrobial activity of saponin from shallot roots against $R$. solanacearum and F. oxysporum.

\begin{tabular}{ccc}
\hline Samples & \multicolumn{2}{c}{ Clear zone diameter $(\mathrm{mm})$} \\
\cline { 2 - 3 } & R. Solanacearum & F. oxysporum \\
\hline BM3 & $10.64 \mathrm{a}$ & $6.52 \mathrm{~b}$ \\
BM2 & $11.42 \mathrm{a}$ & $10.65 \mathrm{ab}$ \\
BM1 & $10.92 \mathrm{a}$ & $6.59 \mathrm{~b}$ \\
TM3 & $11.04 \mathrm{a}$ & $6.74 \mathrm{~b}$ \\
TM2 & $13.33 \mathrm{a}$ & $8.19 \mathrm{ab}$ \\
TM1 & $12.24 \mathrm{a}$ & $7.05 \mathrm{~b}$ \\
BR2 & $10.36 \mathrm{a}$ & $7.58 \mathrm{~b}$ \\
BR1 & $10.69 \mathrm{a}$ & $7.25 \mathrm{~b}$ \\
Chloramphenicol & $7.33 \mathrm{~b}$ & - \\
Nystatin & - & $11.80 \mathrm{a}$ \\
80\% MeOH & $6.94 \mathrm{~b}$ & $5.80 \mathrm{~b}$ \\
\hline
\end{tabular}

Note: means with the same letter in a column are not significantly different according to Tukey's test $(P<0.05)$. Each value is the mean $(n=3)$.

\section{Saponins Antimicrobial Activity}

This result was inconsistent with the previous report that found more antifungal activity in the saponins from $A$. cepa than the antibacterial activity (Lanzotti et al., 2012; Abdelrahman et al., 2014). The saponins has two aglicons, frustanol and spirostanol saponins. The frustanol saponin has been common in A. cepa taxa including onion and shallot (Lanzotti et al., 2012). However, in the qualitative analysis using a TLC plate, those two saponins could not be distinguished from the bands that appeared.

The interesting fact is against $R$. solanacearum, the saponin from shallot root shows high antibacterial activity by suppressing the growth of the bacteria and showing a wider clear zone. Some previous results mentioned that $R$. solacaearum growth could be suppressed by the hexane extract of Acacia stuhlmannii (Nyarieko \& Chigodi, 2016) and hot pepper (Capsicum annuum) leaves (Yihune \& Yemata, 2019). Din et al. (2016) explained clearly the mechanism of saponin antibacterial activity against $R$. solanacearum by using silver nanoparticles containing saponin from Lantana camara L. $R$. solanacearum cell discovered twisted and disrupted and the 
cytoplasm was shrunk based on TEM image captured. The cell wall damage could be the main reason for the bacterial growth inhibition shown as the clear zone.

Although, the result between all samples was not significantly different. The saponins of the shallot roots collected from the second harvesting time tended to have higher antimicrobial activity (BM2 and TM2). In this period, plants have reached maturity and preparing bulb formation as the saponin production is influenced by the plant's physiological status (Szakiel et al., 2011). At the end of the vegetative stage of shallots, the cells have reached their maximum size. They could accumulate more photosynthates to be used for further metabolism processes, including saponin production.

In some cases, on medicinal plants, plant growth and development stages give a big impact on saponins accumulation. The development stages are also related to the plant biomass as the root biomass will increase with the growth and development (Tian et al., 2009). The more accumulation of saponins on the root is closely related to the plant protection mechanism from the abiotic and biotic factors, including pathogens, parasites, and symbiotic bacteria or fungi (Szakiel et al., 2011).

\section{CONCLUSION}

1. Shallot plants cultivated in marginal coastal sandy land produced higher saponins accumulated in the roots as the result of abiotic stress conditions.

2. The saponins production increases along with the maturity of shallot plants, both cultivated in marginal coastal sandy land or regular paddy field.
3. The saponins extracted from the roots of shallots cultivated in both marginal and regular land showed higher antimicrobial activity than antifungal activity.

\section{ACKNOWLEDGMENT}

The research was fully funded by DIPA UNY 2018.

\section{REFERENCES}

Abdelrahman, M., Hirata, S., Ito, S., Yamauchi, N., \& Shigyo, M. (2014). Compartmentation and localization of bioactive metabolites in different organs of Allium roylei. Biosci. Biotechnol. Biochem. 7, 1112-1122. https://doi.org/10.1080/09168451.20 14.915722

Akula, R., \& Ravishankar, G. A. (2011). Influence of abiotic stress signals on secondary metabolites in plants. Plant signaling \& behavior, 6(11), 17201731. https://dx.doi.org/10.4161\%2Fpsb.6.1 1.17613

Almeselmani, M., P. S. Deshmukh, R. K. Sairam, S. R. Kushwaha, \& T. P. Singh. (2006). Protective role of antioxidant enzymes under high-temperature stress. Plant Sci. 171: 382-388. https://doi.org/10.1016/j.plantsci.200 6.04.009

Ariyanti, N. A., V. Q. Hoa, L. I. Khrustaleva, S. Hirata, M. Abdelrahman, S. I. Ito, N. Yamauchi, \& Shigyo, M. (2015). Production and characterization of alien chromosome addition lines in Allium fistulosum carrying extra chromosomes of Allium roylei using molecular and cytogenetic analyses. Euphytica 206: $\quad 343-355$. http://dx.doi.org/10.1007/s10681015-1476-2

Ariyanti, N. A., K. Torikai, R. P. Kirana, S. 
Hirata, E. Sulistyaningsih, S. I. Ito, N. Yamauchi, N. Kobayashi, \& M. Shigyo. (2017). Comparative study on phytochemical variations in Japanese $F_{1}$ varieties of bulb onions and Southeast Asian shallot landraces. Hort. J. DOI: $\quad 10.2503 /$ short.OKD-066. https://doi.org/10.2503/hortj.OKD066

Bruneton, J. (1995). Pharmacognosy, Phytochemistry, Medicinal Plants. Lavoisier Publishing, Paris pp. 538544, ISBN: 2-4730-0028-7.

Budiyanto, G., Aini, L. N., \& Sari, S. A. (2020, February). Land suitability for soybean (Glycine max L. Merill) in sandy coastal land of Parangtritis, Bantul Regency. In IOP Conference Series: Earth and Environmental Science (Vol. 458, No. 1, p. 012007). IOP Publishing. http://dx.doi.org/10.1088/17551315/458/1/012007

Camejo, D., P. Rodríguez, M. A. Morales, J. M. Dell'Amico, A. Torrecillas, \& J. J. Alarcón. (2005). High-temperature effects on photosynthetic activity of two tomato cultivars with different heat susceptibility. J. Plant Physiol. 162:281-289.

https://doi.org/10.1016/j.jplph.2004. 07.014

Din, N., Ahmad, M., Siddique, M., Ali, A., Naz, I., Ullah, N., \& Ahmad, F. (2016). Phytobiocidal management of bacterial wilt of tomato caused by Ralstonia solanacearum (Smith) Yabuuchi. Spanish Journal of agricultural research,14(3), 22. https://doi.org/10.5424/sjar/2016143 $-9012$

Dixon, R.A. (2001). Natural products and plant disease resistance. Nature 411, 843-847. https://doi.org/10.1038/35081178
Ebrahimzadeh, H. (1998). A revised spectrophotometric method for the determination of triterpenoid saponins. Indian Drugs, 35, 379-381.

Ismail, H., Maksimović, J. D., Maksimović, V., Shabala, L., Živanović, B. D., Tian, Y., ... \& Shabala, S. (2016). Rutin, a flavonoid with antioxidant activity, improves plant salinity tolerance by regulating $\mathrm{K}^{+}$retention and $\mathrm{Na}^{+}$exclusion from leaf mesophyll in quinoa and broad beans. Functional Plant Biology, 43(1), 75-86.

https://doi.org/10.1071/fp15312

Kertonegoro, B. D. (2001). Gumuk pasir pantai di DI Yogyakarta: Potensi dan pemanfaatannya untuk pertanian berkelanjutan. Prosiding Seminar Nasional Pemanfaatan Sumberdaya Lokal Untuk Pembangunan Pertanian Berkelanjutan. Universitas Wangsa Manggala pada tanggal (Vol. 2, pp. 4654).

Lanzotti, V. (2012). Bioactive polar natural compounds from garlic and onions. Phytochem. Rev. 11, 179-196. https://doi.org/10.1007/s11101-0129247-3

Laxminarayana, K., \& Subbaiah, G. V. (1995). Effect of mixing of sandy soil with clay vertisol and potassium on yield and nutrient uptake by groundnut. Journal of the Indian Society of Soil Science, 43(4), 691-696.

Mostafa, A., Sudisha, J., El-Sayed, M., Ito, SI., Ikeda, T., Yamauchi, N., \& Shigyo, M. (2013). Aginoside saponin, a potent antifungal compound, and secondary metabolite analyses from Allium nigrum L. Phytochem. Lett. 6, 274-280. http://dx.doi.org/10.1016\%2Fj.phytol. 2013.03.001

Ndamba, J., Robertson, I., Lemmich, E., Chandiwana, S. K., Furu, P., \& 
Mølgaard, P. (1996). Berry productivity and molluscicidal saponin yield of Phytolacca dodecandra (Phytolaccaceae) under different sunlight, watering, and nutrient conditions. Economic Botany,50(2), 151-166.

https://doi.org/10.1007/BF02861447

Nurhayati, D. R. (2019). Growth of sesame (Sesamum indicum L.) plants with mediated compost biochar on coastal sandy land area in Bantul Regency Indonesia. Eurasian Journal of BioSciences, 13(2), 673-679.

Nyarieko, N., \& Chigodi, M. M. P. G. M. (2016). Screening for Bioactivity of Phytochemical Extracted from Acacia stuhlmannii Against Ralstonia solanacearum. Screening, 6(16).

Rajiman, R., Yudono, P., Sulistyaningsih, E., \& Hanudin, E. (2008). Pengaruh pembenah tanah terhadap sifat fisika tanah dan hasil bawang merah pada lahan pasir pantai bugel Kabupaten Kulon Progo. Agrin, 12(1). http://dx.doi.org/10.20884/1.agrin.20 08.12.1.80

Schwarzbach, A., Schreiner, M., \& Knorr, D. (2006). Effect of cultivars and deepfreeze storage on saponin content of white asparagus spears (Asparagus officinalis L.). Eur. Food Res. Technol, 222:32-35.

http://dx.doi.org/10.1007/s00217005-0011-4

Solı'z-Guerrero, J.B., de Rodriguez, D.J., Rodri'guez-Garcl'a, R., AnguloSa'nchez, J.L., \& Me'ndez-Padilla, G. (2002). Quinoa saponins: concentration and composition analysis. In: Janick J, Whipkey A (eds) Trends in new crops and new uses. ASHS Press, Alexandria, pp 110-114.
Syukur, A. (2005). Pengaruh pemberian bahan organik terhadap sifat-sifat tanah dan pertumbuhan caisim di tanah pasir pantai. Jurnal IImu Tanah dan Lingkungan, 5.

Szakiel, A., Pączkowski, C., \& Henry, M. (2011). Influence of environmental biotic factors on the content of saponins in plants. Phytochemistry Reviews, 10(4), 493-502. http://dx.doi.org/10.1007/s11101010-9164-2

Tian, R. T., Xie, P. S., \& Liu, H. P. (2009). Evaluation of traditional Chinese herbal medicine: Chaihu (Bupleuri Radix) by both high-performance liquid chromatographic and highperformance thin-layer chromatographic fingerprint and chemometric analysis. Journal of Chromatography A, 1216(11), 21502155.

https://doi.org/10.1016/j.chroma.200 8.10.127

Verpoorte, R., \& Memelink, J. (2002). Engineering secondary metabolite production in plants. Current opinion in biotechnology, 13(2), 181-187. https://doi.org/10.1016/s09581669(02)00308-7

Wahid, A., S. Gelani, M. Ashraf \& M. R. Foolad. (2007). Heat tolerance in plants: an overview. Environ. Exper. Bot. 61: 199-223. https://doi.org/10.1016/j.envexpbot. 2007.05.011

Wang, Y.X., Feri, M. (2011). Stressed food the impact of abiotic environmental stresses on crop quality. Agric. Ecosyst. Environ. 141, 271-286. http://dx.doi.org/10.1016\%2Fj.agee.2 011.03.017

Widjayanti, E. P. (2011). Severally Wells And Society In Ngentak Hamlet, Bantul, 
Yogyakarta A Study Of EthnologyEthnoscience. In The Second Annual Indonesian Scholars Conference in Taiwan (p. 181).

Yang, A., Akhtar, S. S., Iqbal, S., Qi, Z., Alandia, G., Saddiq, M. S., \& Jacobsen, S. E. (2018). Saponin seed priming improves salt tolerance in quinoa. Journal of Agronomy and Crop Science, 204(1), 31-39. https://doi.org/10.1111/jac.12229
Yihune, E., \& Yemata, G. (2019). Antibacterial activity of medicinal plant extracts against Ralstonia solanacearum (Smith) that causes bacterial wilt in hot pepper (Capsicum annuum L.). Acta Scientiarum. Biological Sciences, 41, e45402e45402.

http://dx.doi.org/10.4025/actascibiol sci.v41i1.45402 